\title{
A juvenile Tristan albatross (Diomedea dabbenena) on land at the Crozet Islands
}

\author{
Alexander L. Bond ${ }^{1,2,4} \oplus$ Christopher Taylor ${ }^{2} \cdot$ David Kinchin-Smith $^{2} \cdot$ Derren Fox $^{2} \cdot$ Emma Witcutt $^{2} \cdot$ Peter G. Ryan $^{3}$. \\ Simon P. Loader ${ }^{4} \cdot$ Henri Weimerskirch ${ }^{5}$
}

Received: 24 June 2020 / Revised: 3 December 2020 / Accepted: 5 December 2020 / Published online: 19 December 2020

(c) The Author(s) 2020

\begin{abstract}
Albatrosses and other seabirds are generally highly philopatric, returning to natal colonies when they achieve breeding age. This is not universal, however, and cases of extraordinary vagrancy are rare. The Tristan Albatross (Diomedea dabbenena) breeds on Gough Island in the South Atlantic Ocean, with a small population on Inaccessible Island, Tristan da Cunha, ca $380 \mathrm{~km}$ away. In 2015, we observed an adult male albatross in Gonydale, Gough Island, which had been ringed on Ile de la Possession, Crozet Islands in 2009 when it was assumed to be an immature Wandering Albatross (D. exulans). We sequenced $1109 \mathrm{bp}$ of the cytochrome $\mathrm{b}$ mitochondrial gene from this bird, and confirmed it to be a Tristan Albatross, meaning its presence on Crozet 6 years previous, and nearly $5000 \mathrm{~km}$ away, was a case of prospecting behaviour in a heterospecific colony. Given the challenges in identifying immature Diomedea albatrosses, such dispersal events may be more common than thought previously.
\end{abstract}

Keywords Crozet islands $\cdot$ Dispersal $\cdot$ Gough island $\cdot$ Prospecting

\section{Introduction}

Many seabirds exhibit a high degree of philopatry, returning to their natal colony to breed after a period of time at sea as pre-breeding immature birds (Hamer et al. 2002). This prebreeding or prospecting period can be lengthy, particularly in albatrosses and petrels (Procellariiformes), where it can last up to 10-15 years (Brooke 2004; Bicknell et al. 2014).

Alexander L. Bond

a.bond@nhm.ac.uk

1 Bird Group, Department of Life Sciences, The Natural History Museum, Akeman Street, Tring, Hertfordshire HP23 6AP, UK

2 RSPB Centre for Conservation Science, Royal Society for the Protection of Birds, The Lodge, Sandy, Bedfordshire SG19 2DL, UK

3 FitzPatrick Institute of African Ornithology, University of Cape Town, Rondebosch 7701, South Africa

4 Vertebrates Division, Department of Life Sciences, The Natural History Museum, Cromwell Road, London SW7 5BD, UK

5 Centre d'Etudes Biologiques de Chizé, CNRS UMR 7372, Université de La Rochelle, 79360 Villiers-en-Bois, France
During this time, immature birds sometimes visit different breeding colonies, though usually settle at their colony of origin where they are recruited into the breeding population (Hamer et al. 2002; Cooper and Weimerskirch 2003; Wails and Major 2017).

Despite this high philopatry, there are often cases of extraordinary dispersal or vagrancy, which can ultimately result in the formation of new breeding colonies (Munilla et al. 2016). Vagrancy to heterospecific breeding sites is reasonably uncommon in albatrosses (Diomedeidae), particularly among the "great albatrosses" (Diomedea spp.) (Phillips et al. 2018). This may, however, be under-reported as these albatrosses are difficult to identify to species level, particularly species in the Wandering Albatross complex (Diomedea exulans, sensu lato) (Cooper et al. 1996). This includes the Tristan Albatross (D. dabbenena), which is the most distinct species genetically within the complex (Nunn and Stanley 1998), but differs in phenotype only in being smaller and generally darker at a given age than Wandering Albatross (Cuthbert et al. 2003).

The Tristan Albatross is listed as Critically Endangered on the IUCN Red List (Birdlife International 2018) with a breeding population of $<2000$ pairs largely restricted to Gough Island (Davies et al. 2015), and 2-3 pairs breeding 
annually on Inaccessible Island, $380 \mathrm{~km}$ north (McClelland et al. 2016; Ryan et al. 2019). It formerly bred on the main island of Tristan da Cunha, but was extirpated in the late nineteenth century (though unconfirmed sightings continued for some time; Bond et al. 2018). It is threatened by introduced mice on Gough Island (Davies et al. 2015; Caravaggi et al. 2019), and bycatch in fisheries at sea (Ryan et al. 2001; Cuthbert et al. 2005, 2004; Wanless et al. 2009). Its at-sea distribution is largely restricted to the South Atlantic Ocean, with individuals occasionally frequenting the western Indian Ocean (Cuthbert et al. 2005; Reid et al. 2013); there are no records of Tristan Albatrosses from other albatross colonies (Phillips et al. 2018).

From 2015-2019 an albatross was caught as part of a long-term demographic study of Tristan Albatrosses in Gonydale, Gough Island (Davies et al. 2015). Unlike albatrosses ringed on Gough and Inaccessible islands, which are fitted with rings from either the South African or British and Irish ringing schemes, this individual had a French ring, indicating it had likely been captured and ringed on the French Southern and Antarctic Territories. Here, we investigate the two possibilities: (1) that a Tristan Albatross from Gough Island was captured on land elsewhere, or (2) that a Wandering Albatross ringed at a French colony had settled on Gough and was attempting to breed with a Tristan Albatross.

\section{Methods}

The albatross was first seen at Gonydale, Gough Island in early 2015 (Figs. 1, 2). It was captured on 29 January 2017 (Fig. 3) and a blood sample taken from the tarsal vein. Blood was collected on Whatman's number 2 filter paper (GE Healthcare, Little Chalfont, UK) and stored at room temperature. To determine its taxonomic identity, we sequenced part of the cytochrome $b$ region of its mitochondrial DNA, and this was compared with the homologous region for other Diomedea species. Total DNA was extracted using the DNeasy blood and tissue kit (Qiagen, Valencia, CA). Amplification and sequencing followed standard protocols using primers (L14863 vs H15915) and methods outlined in Nunn et al. (1996). Sequences were checked and a consensus sequence compiled in Geneious v8.1.9 (Kearse et al. 2012). The consensus sequence was compared on BLAST (https:// blast.ncbi.nlm.nih.gov/Blast.cgi).

\section{Results}

The albatross was first caught at Ile de la Possession on 20 April 2009 in the colony of Chaloupe sud, a small colony of 10-15 scattered nests on the eastern coast of the island (Fig. 2). It was presumed to be a visiting immature Wandering Albatross and it was given French ring BS28275 and released; on Possession all Wandering Albatrosses have been captured and ringed annually since 1966 (Weimerskirch 2018). It was subsequently caught on Gough Island, nearly $5000 \mathrm{~km}$ away, on 7 January 2015 and a yellow colour
Fig. 1 An adult male Tristan Albatross breeding on Gough Island in 2015 with French ring BS28275 visible on the left leg. Photo: D. Fox

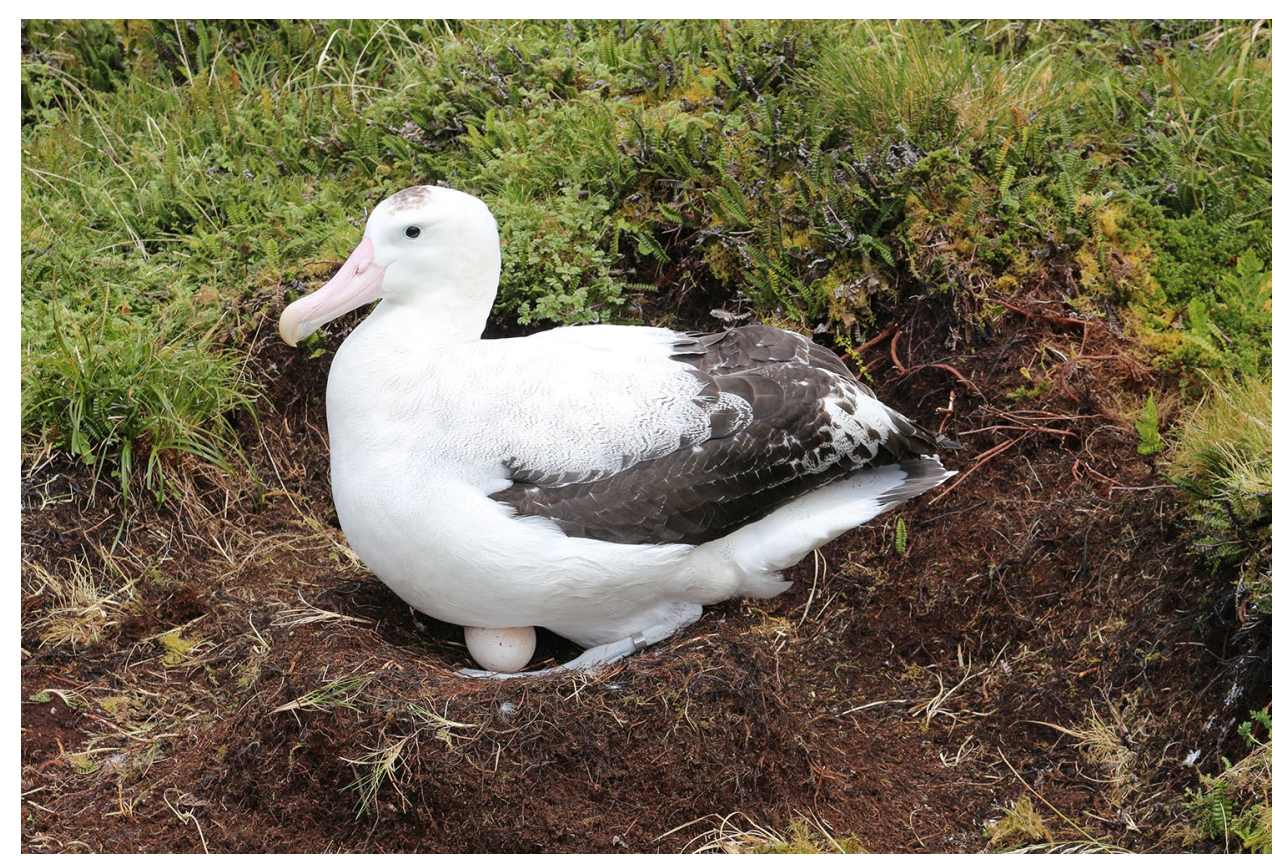




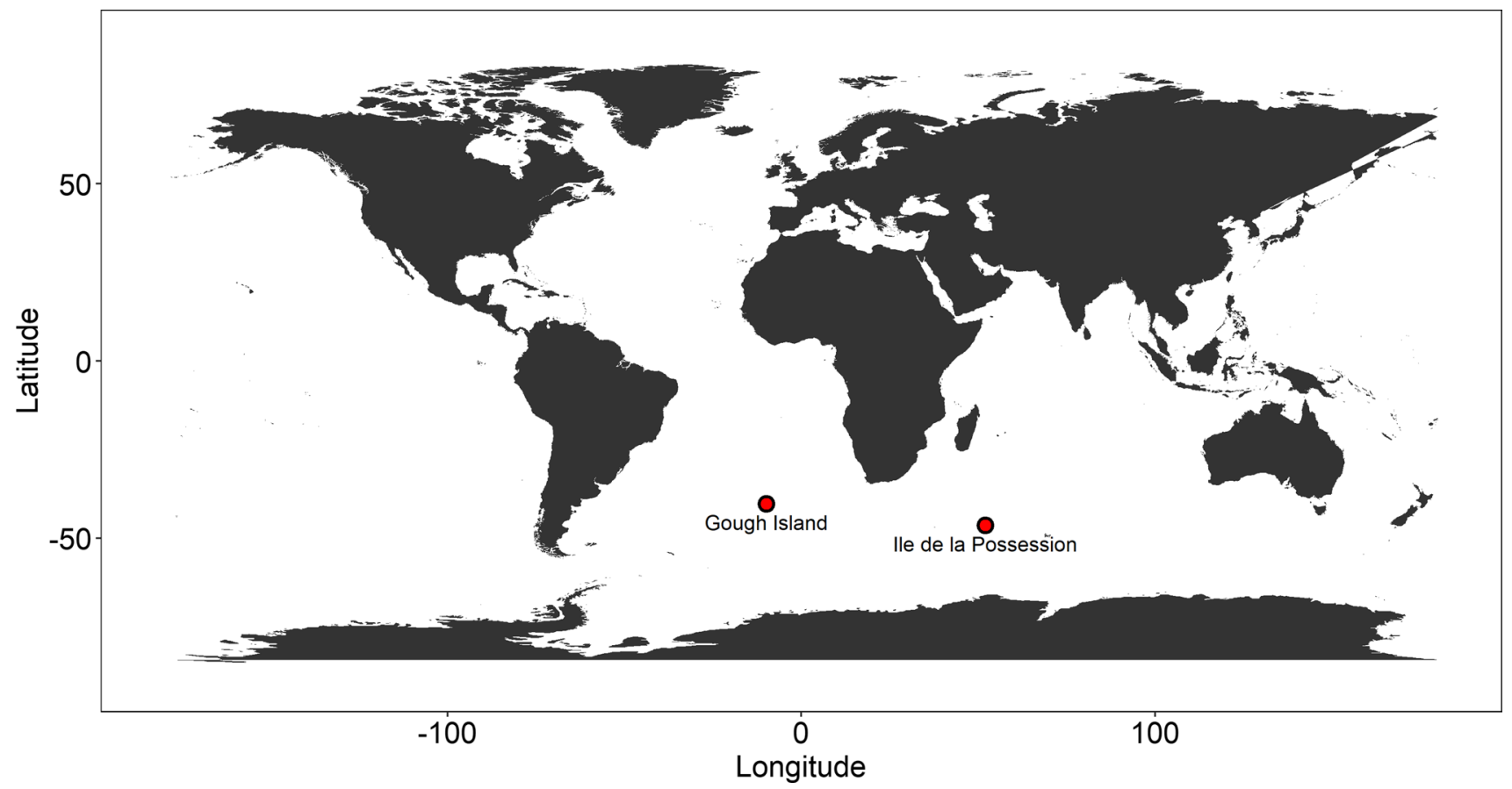

Fig. 2 Map showing the locations of Gough Island, where the bird was recaptured, and Ile de la Possession, where the bird was originally ringed

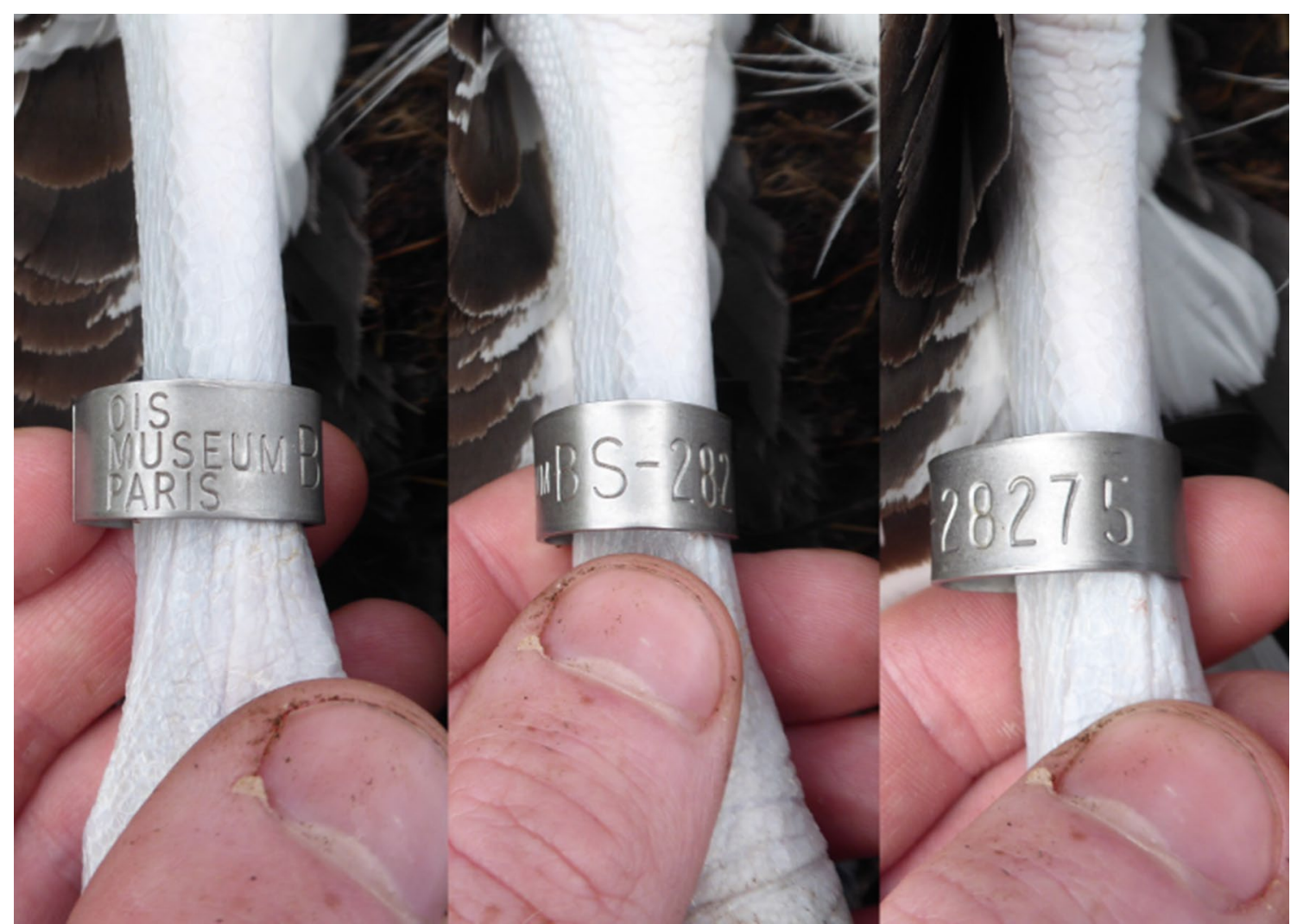

Fig. 3 French ring BS-28275 on an adult Tristan Albatross on Gough Island in 2017. Photo: D. Kinchin-Smith 
ring with black text "N33" was added. That year, it was paired with an unringed female Tristan Albatross, and failed at the egg stage between 12 and 23 April. In 2016, it was paired with a female Tristan Albatross of unknown age (ring J22682), and the egg failed between 18 February and 30 March. In 2017 it was paired with the same female, and successfully raised a chick, and like many successful breeders it skipped breeding in 2018. It returned in 2019 and paired with the same female again, resulting in another successfully fledged chick.

We sequenced 1109 base pairs of the cytochrome $b$ gene and this was a $100 \%$ match with the sequence from Diomedea dabbenena reported by Cooper et al. (1996) and collected from Gough Island (GenBank accession MT561023).

\section{Discussion}

The distribution and at-sea movements of adult breeding and non-breeding Tristan Albatrosses have been studied (Cuthbert et al. 2005; Reid et al. 2013; Dias et al. 2017), but given the lengthy pre-breeding phase of juvenile Tristan Albatrosses, up to 18 years (Cuthbert et al. 2004), and difficulty in separating young birds from those of other Diomedea spp. albatrosses at-sea (e.g., Onley and Scofield 2007), their distribution and habitat associations are unknown. Advances in satellite telemetry and the decreasing cost of biologgers could fill this data gap in the future (ACAP 2019; Phillips et al. 2016).

Tristan Albatrosses breed primarily on Gough Island, but with a small though persisting population of 2-3 pairs on Inaccessible Island, $380 \mathrm{~km}$ away (McClelland et al. 2016). Whether this relict population, which formerly numbered ca. 200 breeding pairs (Stoltenhoff 1952), and birds seen sporadically on Tristan are from Gough Island or are from a self-sustaining population on the predator-free Inaccessible Island is unknown. Movement among colonies has been documented previously in Wandering Albatrosses, most notably between Crozet and Prince Edward Islands, more than $1000 \mathrm{~km}$ apart, with $>60$ instances of ringed birds moving, though the vast majority of these (57, or 93\%) from Crozet to Prince Edward (Cooper and Weimerskirch 2003). Wandering Albatrosses are also genetically homogenous with little population structure, suggesting sporadic gene flow among distant colonies (Milot et al. 2008).

There are several notable cases of vagrant albatrosses on land, ranging from brief visits of a Salvin's Albatross (Thalassarche salvini) on Gough Island (Visser et al. 2009), to a Black-browed Albatross (Thalassarche melanophrys) that frequented the Northern Gannet (Morus bassanus) colony on Mykines, Faroe Islands, for 30 years, and engaged in nest building, now a specimen in the Natural History Museum of
Denmark (NHMD 867678) (Andersen 1894; Phillips et al. 2018).

In many seabirds, immature birds who have not yet begun breeding may prospect at several colonies, often over large distances, but most will return to their natal colony, or one nearby (e.g., Inchausti and Weimerskirch 2002; Breton et al. 2006; Bicknell et al. 2014). This is, however, not universal, and few species where it has been quantified have shown near universal philopatry (Coulson 2016). Given the lengthy pre-breeding period of many seabirds, and albatrosses in particular, and the challenges in distinguishing Diomedea spp. albatrosses in immature plumage (Cuthbert et al. 2003), prospecting at heterospecific colonies may be more common than previously recognized.

Acknowledgements We thank the Tristan da Cunha Administrator, Island Council, and Conservation Department for permission to work on Gough Island, and administration of the Terres australes et antarctiques françaises for permission to work on Crozet Island, the dedicated field teams on Gough and Possession for their hard work, and S. Oppel (RSPB) for information on the breeding history of this bird. S. Hammer (Umhvørvisstovan/Faroese Environment Agency), and J. B. Kristensen (Statens Naturhistoriske Museum/Natural History Museum of Denmark) provided details of the Faroese albatross. Comments from anonymous reviewers improved this manuscript.

Author contributions ALB wrote the manuscript and directed field work on Gough. CT, DF, DKS, and EW conducted field work and collected samples. PGR directed field work. SPL conducted genetic analyses. HW directed field work on Crozet. All authors edited the manuscript.

Funding The Royal Society for the Protection of Birds (RSPB) and FitzPatrick Institute of African Ornithology, University of Cape Town funded field work on Gough Island, and Institut Polaire Français (IPEV Program 109) on Crozet.

Data availability Molecular data are deposited in GenBank; all other data are contained in the manuscript.

\section{Compliance with ethical standards}

Conflict of interests All authors declare that they have no conflict of interest.

Ethical approval Work was carried with permission from the Tristan da Cunha Government, with ringing authorised by the Centre de Recherches sur la Biologie des Populations d'Oiseaux/Museum National d'Histoire Naturelle, and the British Trust for Ornithology.

Open Access This article is licensed under a Creative Commons Attribution 4.0 International License, which permits use, sharing, adaptation, distribution and reproduction in any medium or format, as long as you give appropriate credit to the original author(s) and the source, provide a link to the Creative Commons licence, and indicate if changes were made. The images or other third party material in this article are included in the article's Creative Commons licence, unless indicated otherwise in a credit line to the material. If material is not included in the article's Creative Commons licence and your intended use is not permitted by statutory regulation or exceeds the permitted use, you will 
need to obtain permission directly from the copyright holder. To view a copy of this licence, visit http://creativecommons.org/licenses/by/4.0/.

\section{References}

ACAP (2019) Report of the Population and Conservation Status Working Group; Eleventh Meeting of the Advisory Committee, Florenópolis, Brazil, 13-17 (2019) AC11 Doc 09. Agreement on the Conservation of Albatrosses and Petrels, Florenópolis, Brazil

Andersen K (1894) Diomedea melanophrys, boende paa Færøerne. Vidensk Meddel. Natuirist Foren Kjobenhavn 1894:241-264

Bicknell AWJ et al (2014) Intercolony movement of pre-breeding seabirds over oceanic scales: implications of cryptic age-classes for conservation and metapopulation dynamics. Divers Distrib 20:160-168. https://doi.org/10.1111/ddi.12137

Birdlife International (2018) Diomedea dabbenena. The IUCN Red List of Threatened Species. https://doi.org/10.2305/IUCN. UK.2018-2.RLTS.T22728364A132657527.en

Bond AL, Carlson CJ, Burgio KR (2018) Local extinctions of insular avifauna on the most remote inhabited island in the world. J Ornithol 160:49-60. https://doi.org/10.1007/s10336-018-1590-8

Breton AR, Diamond AW, Kress SW (2006) Encounter, survival, and movement probabilities from an Atlantic Puffin (Fratercula arctica) metapopulation. Ecol Monogr 76:133-149. https://doi. org/10.1890/05-0704

Brooke M (2004) Albatrosses and Petrels Across the World. Oxford University Press, New York

Caravaggi A, Cuthbert RJ, Ryan PG, Cooper J, Bond AL (2019) The impacts of introduced House Mice on the breeding success of nesting seabirds on Gough Island. Ibis 161:648-661. https://doi. org/10.1111/ibi.12664

Cooper J, Weimerskirch H (2003) Exchange of the wandering albatross Diomedea exulans between the prince Edward and Crozet islands: implications for conservation. Afr J Mar Sci 25:519-523. https:// doi.org/10.2989/18142320309504040

Cooper J, Jouventin P, Robertson GG (1996) Evolutionary Relationships among Extant Albatrosses (Procellariiformes Diomedeidae) Established from Complete Cytochrome-B Gene Sequences. Auk 113:784-801. https://doi.org/10.2307/4088857

Coulson JC (2016) A review of philopatry in seabirds and comparisons with other waterbird species. Waterbirds 39:229-240. https://doi. org/10.1675/063.039.0302

Cuthbert R, Hilton G, Ryan P, Tuck GN (2005) At-sea distribution of breeding Tristan albatrosses Diomedea dabbenena and potential interactions with pelagic longline fishing in the South Atlantic Ocean. Biol Conserv 121:345-355. https://doi.org/10.1016/j.bioco n.2004.05.007

Cuthbert RJ, Phillips RA, Ryan PG (2003) Separating the Tristan Albatross and the Wandering Albatross Using Morphometric Measurements. Waterbirds 26:338-344. https://doi.org/10.1675/15244695(2003)026[0338:sttaat]2.0.co;2

Cuthbert RJ, Sommer E, Ryan P, Cooper J, Hilton G (2004) Demography and conservation of the Tristan Albatross Diomedea [exulans] dabbenena. Biol Conserv 117:471-481. https://doi.org/10.1016/j. biocon.2003.08.006

Davies D, Dilley BJ, Bond AL, Cuthbert RJ, Ryan PG (2015) Trends and tactics of mouse predation on Tristan Albatross Diomedea dabbenena chicks at Gough Island. South Atlantic Ocean Avian Conserv Ecol 10:5. https://doi.org/10.5751/ace-00738-100105

Dias MP et al (2017) Using globally threatened pelagic birds to identify priority sites for marine conservation in the South Atlantic Ocean. Biol Conserv 211:76-84. https://doi.org/10.1016/j.bioco n.2017.05.009
Hamer KC, Schreiber EA, Burger J (2002) Breeding biology, life histories and life history-environment interactions in seabirds. In: Schreiber EA, Burger J (eds) Biology of Marine Birds. CRC Press, New York, pp 217-261

Inchausti P, Weimerskirch H (2002) Dispersal and metapopulation dynamics of an oceanic seabird, the wandering albatross, and its consequences for its response to long-line fisheries. J Anim Ecol 71:765-770. https://doi.org/10.1046/j.1365-2656.2002.00638.x

Kearse $\mathrm{M}$ et al (2012) Geneious Basic: An integrated and extendable desktop software platform for the organization and analysis of sequence data. Bioinformatics 28:1647-1649. https://doi. org/10.1093/bioinformatics/bts199

McClelland GTW, Bond AL, Sardana A, Glass T (2016) Rapid population estimate of a surface-nesting seabird on a remote island using a low-cost unmanned aerial vehicle. Mar Ornithol 44:215-220

Milot E, Weimerskirch H, Bernatchez L (2008) The seabird paradox: dispersal, genetic structure and population dynamics in a highly mobile, but philopatric albatross species. Mol Ecol 17:1658-1673. https://doi.org/10.1111/j.1365-294X.2008.03700.x

Munilla I, Genovart M, Paiva VH, Velando A (2016) Colony foundation in an oceanic seabird. PLoS ONE 11:e0147222. https://doi. org/10.1371/journal.pone.0147222

Nunn GB, Stanley SE (1998) Body size effects and rates of cytochrome $b$ evolution in tube-nosed seabirds. Mol Biol Evol 15:1360-1371. https://doi.org/10.1093/oxfordjournals.molbev.a025864

Onley D, Scofield P (2007) Albatrosses, petrels, and shearwaters of the world. Princeton University Press, Princeton, USA

Phillips RA et al (2016) The conservation status and priorities for albatrosses and large petrels. Biol Conserv 201:169-183. https://doi. org/10.1016/j.biocon.2016.06.017

Phillips RA, Cooper J, Burg TM (2018) Breeding-site vagrancy and hybridization in albatrosses. Ibis 160:907-913. https://doi. org/10.1111/ibi.12622

Reid TA, Wanless RM, Hilton GM, Phillips RA, Ryan PG (2013) Foraging range and habitat associations of non-breeding Tristan albatrosses: overlap with fisheries and implications for conservation. Endang Species Res 22:39-49

Ryan PG, Cooper J, Glass JP (2001) Population status, breeding biology and conservation of the Tristan Albatross Diomedea [exulans] dabbenena. Bird Conserv Int 11:35-48. https://doi.org/10.1017/ s0959270901001058

Ryan PG, Dilley BJ, Ronconi RA (2019) Population trends of Spectacled Petrels Procellaria conspicillata and other seabirds at Inaccessible. Island Mar Ornithol 47:257-265

Stoltenhoff F (1952) Notes on birds on Inaccessible Island. In: Rosenthal E (ed) Shelter from the spray. Cape Times, Parrow, Australia,

Visser P, Louw H, Cuthbert RJ, Ryan PG (2009) Salvin's albatross Thalassarche salvini on Gough Island. South Atlantic. Bull Afr Bird Club 16:215-216

Wails CN, Major HL (2017) Fitting in with the crowd: the role of prospecting in seabird behavioural trends. Can J Zool 95:247-253. https://doi.org/10.1139/cjz-2016-0166

Wanless RM, Ryan PG, Altwegg R, Angel A, Cooper J, Cuthbert RJ, Hilton GM (2009) From both sides: Dire demographic consequences of carnivorous mice and longlining for the Critically Endangered Tristan albatrosses on Gough Island. Biol Conserv 142:1710-1718

Weimerskirch H (2018) Linking demographic processes and foraging ecology in wandering albatross-Conservation implications. J Anim Ecol 87:945-955. https://doi.org/10.1111/1365-2656.12817

Publisher's Note Springer Nature remains neutral with regard to jurisdictional claims in published maps and institutional affiliations. 